\title{
In vivo $B_{1}$ kinin-receptor upregulation. Evidence for involvement of protein kinases and nuclear factor $\kappa B$ pathways
}

\author{
${ }^{1}$ Maria M. Campos, ${ }^{2}$ Glória E. P. Souza \& ${ }^{*, 1}$ João B. Calixto
}

${ }^{1}$ Department of Pharmacology, Centre of Biological Sciences, Universidade Federal de Santa Catarina, Rua Ferreira Lima, 82, 88015-420, Florianópolis, SC, Brazil and ${ }^{2}$ Laboratory of Pharmacology, Faculty of Pharmacy, USP, Ribeirão Preto, Brazil

\begin{abstract}
1 Intradermal (i.d.) injection of cytokines, IL-1 $\beta$ and $\mathrm{TNF} \alpha$ (5 ng, 60 and 30 min prior) produces a rapid onset up-regulation of des-Arg'-BK-mediated rat paw oedema. Here we analyse the mechanisms involved in des-Arg ${ }^{9}-\mathrm{BK}$-induced oedema in animals pre-treated with IL- $1 \beta$ or $\mathrm{TNF} \alpha$.

2 Co-injection of anti-IL-1 $\beta$, anti-TNF $\alpha$ and anti-IL-8 (50 ng) significantly inhibited des-Arg'-BKinduced oedema in animals pre-treated with $\operatorname{IL}-1 \beta(65,37$ and $42 \%)$ or TNF $\alpha(39,64,25 \%)$. IL-1 receptor antagonist (IRA, $100 \mu \mathrm{g})$ or IL-10 (10 ng) inhibited the oedema caused by des-Arg 9 -BK, in rats that had received either IL-1 $\beta$ (67 and $63 \%)$ or TNF $\alpha$ (46 and $35 \%)$.

3 Co-injection of the PKC inhibitors, staurosporine (10 nmol) or RO 318220 (30 nmol) inhibited des-Arg ${ }^{9}$-BK-induced paw oedema (44 and $42 \%$ for IL- $1 \beta$ and, 53 and $30 \%$ for TNF $\alpha$, respectively). Genistein (tyrosine kinase inhibitor, $2.5 \mathrm{mg} \mathrm{kg}^{-1}$, s.c.) or PD 098059 (MAP-kinase inhibitor, $30 \mathrm{nmol}$ ) produced marked inhibition of des-Arg ${ }^{9}-\mathrm{BK}$-induced oedema (58 and $39 \%$ for IL- $1 \beta$ and 31 and $35 \%$ for $\mathrm{TNF} \alpha$ respectively).

4 The NF- $\kappa$ B inhibitors TLCK (2 $\mathrm{mg} \mathrm{kg}^{-1}$, i.p.) and PDCT (100 $\mathrm{mg} \mathrm{kg}^{-1}$, i.p.) significantly inhibited the oedema of des-Arg $-\mathrm{BK}$ in IL-1 $\beta$ (27 and $83 \%$ ) or TNF $\alpha$ (28 and $80 \%)$ pre-treated animals.

5 It is concluded that up-regulation of $\mathrm{B}_{1}$ receptors modulated by IL- $1 \beta$ or TNF $\alpha$ involves the release of other cytokines, activation of PKC and tyrosine kinase pathways, co-ordinated with the activation of MAP-kinase and nuclear factor $\kappa \mathrm{B}$, reinforcing the view that $\mathrm{B}_{1}$ receptors may exert a pivotal role in modulating chronic inflammatory processes.
\end{abstract}

Keywords: $\mathrm{B}_{1}$ kinin receptor; cytokines; protein kinases; nuclear factor $\kappa \mathrm{B}$

Abbreviations: BCG, Mycobacterium bovis bacillus Calmette-Guérin; BK, bradykinin; des-Arg'-BK, des-Arg9-bradykinin; IL, interleukin; IRA, interleukin receptor antagonist; MAP-kinase, mitogen-activated protein kinase; NF- $\kappa \mathrm{B}$, nuclear factor $\kappa \mathrm{B}$; PBS, phosphate buffered saline; PDTC, pyrrolidine-dithiocarbamate; PKC, protein kinase C; TLCK, N $\alpha$-tosyl-L-chloromethylketone; TNF $\alpha$, tumor necrosis factor $\alpha$

\section{Introduction}

Kinins are endogenous peptides formed in plasma and peripheral tissues in response to trauma or infection, or during inflammatory processes, from kininogen precursors, by the action of serine protease kallikreins. Kinins are involved in many physiological processes, such as control of blood pressure, increase of blood flow and vascular permeability, oedema formation at the site of injury and induction of pain and hyperalgesia (Regoli \& Barabé, 1980; Bhoola et al., 1992; Hall, 1992).

The actions of kinins are mediated by the activation of two receptor subtypes, $\mathrm{B}_{1}$ and $\mathrm{B}_{2}$. The genes that encode these receptors have been cloned in several animal species, being receptors with seven transmembrane domains, coupled to G proteins (Eggerix et al., 1992; Hess et al., 1992; 1994; McEachern et al., 1991; Pesquero et al., 1996). The $\mathrm{B}_{2}$ receptors are constitutively expressed throughout either the central or peripheral nervous system, mediating the majority of pharmacological actions evoked by kinins and exhibiting high affinity for bradykinin (BK) and kallidin. On the other hand, the $B_{1}$ receptors show higher affinity for the kinin metabolites des-Arg ${ }^{9}-\mathrm{BK}$ and des-Arg ${ }^{10}$-kallidin, and are in some manner atypical, as their expression is often inducible. The $\mathrm{B}_{1}$ receptors are upregulated after tissue trauma or

* Author for correspondence; E-mail: Calixto@farmaco.ufsc.br following challenge of animals with certain agents, such as endotoxins, Freund's adjuvant, some cytokines or Mycobacterium bovis bacillus Calmette-Guérin (BCG) (Marceau, 1995; 1997; Campos et al., 1996; 1997; Hall, 1997; Hall \& Morton 1997).

Recently, it has been suggested that the mechanisms mediating the expression of inducible receptors, including $\mathrm{B}_{1}$, may involve the activation of a common signalling pathway, involving some specific transcription factors, allowing the rapid expression of the receptors, under some special circumstances (Donaldson et al., 1997). Nuclear factor $\kappa \mathrm{B}$ $(\mathrm{NF}-\kappa \mathrm{B})$ is a well-characterized transcription factor, activated by several stimuli, especially bacterial products and some of the cytokines. Its most usual form is a heterodimer, composed of two subunits p50 and p65, that is normally found inactive in cytoplasm and bound to an inhibitory protein $1 \kappa$-B. When cells are stimulated, specific kinases phosphorylate $1-\kappa \mathrm{B}$, causing its rapid degradation. Then, $\mathrm{NF}-\kappa \mathrm{B}$ translocates to the nucleus and activates a series of target genes, including cytokines, inflammatory enzymes and inflammatory receptors (Barnes \& Adcock, 1997; Barnes \& Karin, 1997; Donaldson et al., 1997). The mechanism(s) by which $1 \kappa \mathrm{B}$ is phosphorylated remains unclear, but recent data (Ghoda et al., 1997) suggest the possible involvement of a protein with $90 \mathrm{KDa}$, which belongs to the mitogenactivated protein-kinase (MAP-kinases) family. This class of 
proteins includes a group of serine/threonine kinases, which are activated by dual phosphorylation on the threonine and tyrosine residues, in response to many extracellular signs (Whitmarsh \& Davis, 1996). It has recently been demonstrated (Larrivé et al., 1998) that $\mathrm{B}_{1}$ receptor up-regulation in isolated rabbit aorta involves the activation of some MAP-kinases. Ni et al. (1998) reported the existence of a sequence containing a NF- $\kappa \mathrm{B}-$ like binding site on the promoter of the human kinin $\mathrm{B}_{1}$ receptor, sufficient for the $\mathrm{B}_{1}$ receptor transcription, following exposure to some inflammatory agents such as LPS, IL-1 $\beta$ or TNF $\alpha$ in vascular smooth muscle cells. In addition, it has also been shown that in cultured human lung fibroblasts, the upregulation of kinin $\mathrm{B}_{1}$ receptor by stimulus with IL-1 $\beta$ is strongly related to the activation of NF- $\kappa \mathrm{B}$ (Schanstra et al., 1998). However, in spite of this molecular evidence, so far there are no in vivo studies demonstrating the role played by $\mathrm{NF}-\kappa \mathrm{B}$ and kinase phosphorylation on the upregulation of the $\mathrm{B}_{1}$ receptor.

We have recently demonstrated that i.d. injection of the cytokines IL- $1 \beta$ and $\mathrm{TNF} \alpha$ produces a rapid up-regulation of $\mathrm{B}_{1}$ receptor-mediated rat paw oedema, without affecting the responses mediated by activation of $\mathrm{B}_{2}$ receptors, in a process largely sensitive to dexamethasone and cycloheximide, requiring the activation of both cyclo-oxygenase- 1 and 2 (Campos et al., 1998). In the present study, we have therefore investigated, in detail, some in vivo mechanisms involved in kinin $\mathrm{B}_{1}$ receptor up-regulation following i.d. injection of IL- $1 \beta$ or TNF $\alpha$. Attempts have also been made in order to investigate further the role of some specific kinases, and also, the participation of $\mathrm{NF}-\kappa \mathrm{B}$ pathways in modulating the increase of functional responses mediated by $\mathrm{B}_{1}$ receptors in vivo, in animals treated with IL- $1 \beta$ or TNF $\alpha$.

\section{Methods}

\section{Measurement of rat paw oedema}

Experiments were conducted with non-fasted male Wistar rats $(140-180 \mathrm{~g}) \mathrm{kept}$ in controlled room temperature $\left(22 \pm 2^{\circ} \mathrm{C}\right)$ under a $12 \mathrm{h:} 12 \mathrm{~h}$ light-dark cycle (lights on $06.00 \mathrm{~h}$ ). All animals were pre-treated with the angiotensin-converting enzyme inhibitor, captopril $\left(5 \mathrm{mg} \mathrm{kg}^{-1}\right.$, s.c.) $1 \mathrm{~h}$ before any experiment, in order to prevent the degradation of peptides (Corrêa \& Calixto, 1993; Campos \& Calixto, 1995). The animals received a $0.1 \mathrm{ml}$ i.d. injection in one hindpaw (right paw) of phosphate buffered saline (PBS, composition mmol $1^{-1}$ : $\mathrm{NaCl} 137$, KCL 2.7 and phosphate buffer 10) containing des-Arg ${ }^{9}$-BK $\left(100 \mathrm{nmol} \mathrm{paw}^{-1}\right)$ or BK (3 nmol paw $^{-1}$ ). The contralateral paw (left paw) received $0.1 \mathrm{ml}$ of PBS and was used as control. Oedema was measured by use of a plethysmometer (Ugo Basile) at several time-points (10, 20, 30,60 and $120 \mathrm{~min}$ ) or only at the peak (20 min) after injection of peptides. Oedema is expressed in $\mathrm{ml}$ as the difference between the right and left paws.

In most experiments, animals were treated with the cytokines IL- $1 \beta$ or TNF $\alpha\left(5 \mathrm{ng} \mathrm{paw}^{-1}\right)(60$ and 30 min before injection of des-Arg'-BK, respectively) at the same site of injection of kinins, as described previously (Campos et al., 1998). In all experiments, the i.d. injections were performed under slight anaesthesia with 2,2,2 tribromoethanol $\left(0.125 \mathrm{~g} \mathrm{~kg}^{-1}\right)$. The reported experiments were carried out in accordance with current guidelines for the care of laboratory animals and ethical guidelines for investigations of experiments in conscious animals (Zimmermann, 1983).
Analysis of the mechanisms involved in $B_{1}$-receptor-mediated paw oedema in rats pre-treated with IL-1 $\beta$ or $T N F \alpha$

In another series of experiments, to assess the possible participation of secondary cytokine synthesis on des-Arg ${ }^{9}$ BK-induced rat paw oedema, animals received an i.d. injection of the anti-murine antibodies anti-IL- $1 \beta$, anti-TNF $\alpha$, anti-IL- 8 or anti-IL-6 $\left(50-100 \mathrm{ng} \mathrm{paw}^{-1}\right)$, co-injected with the cytokines IL- $1 \beta$ and $\mathrm{TNF} \alpha$ (both $5 \mathrm{ng} \mathrm{paw}^{-1}$ ), 60 and $30 \mathrm{~min}$ before the injection of des-Arg-BK $\left(100 \mathrm{nmol} \mathrm{paw}^{-1}\right)$, respectively. Other animals received IL-1 $\beta$ or TNF $\alpha$ ( $5 \mathrm{ng} \mathrm{paw}^{-1}$ ) in association with the recombinant interleukin receptor antagonist (IRA, $100 \mu \mathrm{g} \mathrm{paw}^{-1}$ ) or with the antiinflammatory cytokine, IL-10 $\left(10-30 \mathrm{ng} \mathrm{paw}^{-1}\right)$.

To investigate the possible involvement of protein kinase $\mathrm{C}$ (PKC) activation in rat paw oedema-induced by des-Arg ${ }^{8}-\mathrm{BK}$ animals received an i.d. injection of staurosporine (10$\left.50 \mathrm{nmol} \mathrm{paw}^{-1}\right)$ or RO $318220\left(30-50 \mathrm{nmol} \mathrm{paw}^{-1}\right)$ in combination with either IL- $1 \beta$ or $\operatorname{TNF} \alpha\left(5 \mathrm{ng} \mathrm{paw}^{-1}\right)$. Other groups of rats received an i.d. injection of PD98059 (a MAPkinase inhibitor, 30 to $50 \mathrm{nmol} \mathrm{paw}^{-1}$ ) in order to evaluate the participation of MAP-kinase pathway in $\mathrm{B}_{1}$ receptor upregulation after IL- $1 \beta$ or $\mathrm{TNF} \alpha$ i.d. injection. In a separate series of experiments, the animals were pre-treated with the tyrosinekinase inhibitor, genistein ( 2.5 to $5 \mathrm{mg} \mathrm{kg}^{-1}$, s.c.) $30 \mathrm{~min}$ before injection of cytokines. Finally, to assess the possible involvement of $\mathrm{NF}-\kappa \mathrm{B}$ in development of $\mathrm{B}_{1}$-receptor mediated paw oedema in rats that had received IL- $1 \beta$ or TNF $\alpha$, the animals were pretreated with the NF- $\kappa$-B inhibitors, PDCT (100 $\mathrm{mg} \mathrm{kg}^{-1}$, i.p.) or TLCK $\left(2 \mathrm{mg} \mathrm{kg}^{-1}\right.$, i.p.) $30 \mathrm{~min}$ before injection of the proinflammatory cytokines. In other groups of experiments, to assess the selectivity of these drugs, the effects of staurosporine, RO318220, PD098059, genistein, PDTC or TLCK (at the same range of doses) were tested against BK $\left(3 \mathrm{nmol} \mathrm{paw}^{-1}\right)$-induced rat paw oedema.

\section{Drugs}

The following drugs were used: des-Arg'-bradykinin, bradykinin, captopril, staurosporine, N $\alpha$-tosyl-L-chloromethylketone (TLCK), pyrrolidine-dithiocarbamate (PDCT). 2,2,2 tribromoethanol, PBS tablets (all from Sigma Chemical Company, St. Louis, U.S.A.). Genistein, PD98059 and RO31820 (Research Biochemical International, RBI, MA, U.S.A.). Recombinant murine cytokines IL-1 $\beta$ (Lot BN091), TNF $\alpha$ (Lot CS184) and IL-10 (Lot BC110); anti-murine neutralizing antibodies anti-IL-1 $\beta$ (Lot B01D3), anti-TNF $\alpha$ (Lot CT101), anti-IL-6 (Lot BF 123), anti-IL-8 (Lot BB282) and human recombinant interleukin receptor antagonist (IRA) were obtained from R\&D Systems Inc., Minneapolis, U.S.A. The stock solutions for all peptides used were prepared in PBS in siliconized plastic tubes maintained at $-18^{\circ} \mathrm{C}$ and diluted to the desired concentration just before use. The other drugs were prepared daily in $0.9 \% \mathrm{w} \mathrm{v}^{-1} \mathrm{NaCl}$ solution.

\section{Statistical analysis}

The results are presented as the mean \pm s.e.mean of 4-6 animals. The percentages of inhibition are reported as mean \pm s.e.mean of inhibitions obtained in each individual experiment at the peak of oedema (20 min after injection of the peptides). Statistical comparison of the data was performed by analysis of variance (ANOVA) followed by Dunnett's test or by use of Student's unpaired $t$-test. $P$ values less than 0.05 were considered significant. 


\section{Results}

As reported previously (Campos \& Calixto, 1995; Campos et al., 1996; 1997), i.d. injection of the selective kinin $\mathrm{B}_{1}$ receptor agonist des-Arg'-BK $\left(100 \mathrm{nmol} \mathrm{paw}^{-1}\right)$ in naive animals produced a very weak increase in rat paw oedema $(0.07 \pm 0.004 \mathrm{ml}, n=5)$. In contrast, i.d. injection of des-Arg9'-
BK in rats that had been treated i.d. with either IL-1 $\beta$ (5 ng paw ${ }^{-1}, 60 \mathrm{~min}$ before) or $\mathrm{TNF} \alpha\left(5 \mathrm{ng} \mathrm{paw}^{-1}, 30 \mathrm{~min}\right.$ before) (Campos et al., 1998) caused a marked increase in rat paw oedema $(0.58 \pm 0.02$ and $0.44 \pm 0.03 \mathrm{ml}, n=5$, respectively).

The oedemas induced by des-Arg $-\mathrm{BK}\left(100 \mathrm{nmol} \mathrm{paw}^{-1}\right)$ in rats pre-treated with either IL-1 $\beta$ (Figure $1 \mathrm{~A}, \mathrm{C}$ and $\mathrm{E}$ ) or
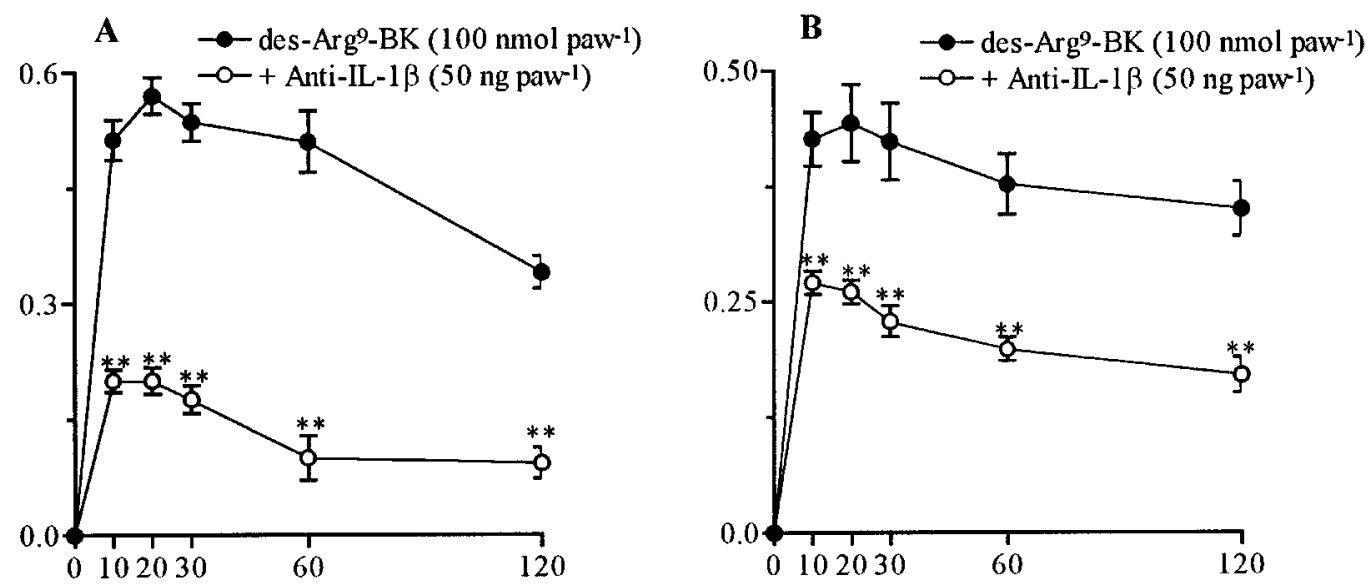

C

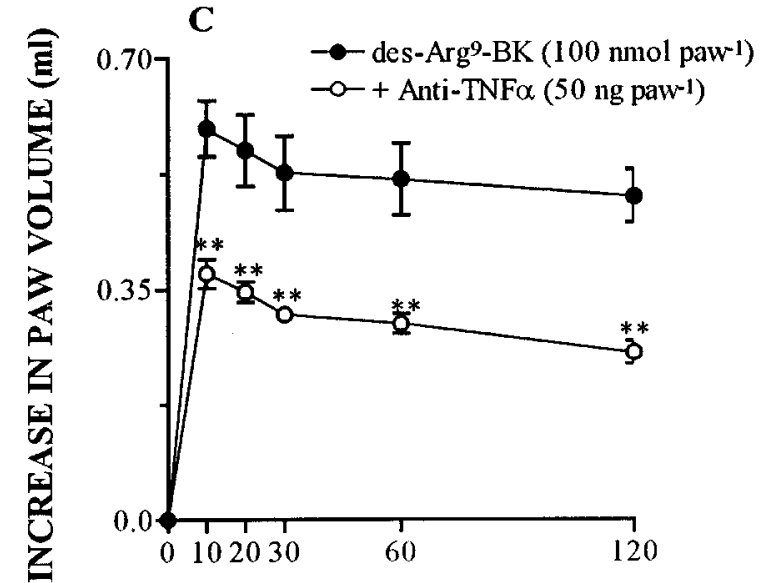

D
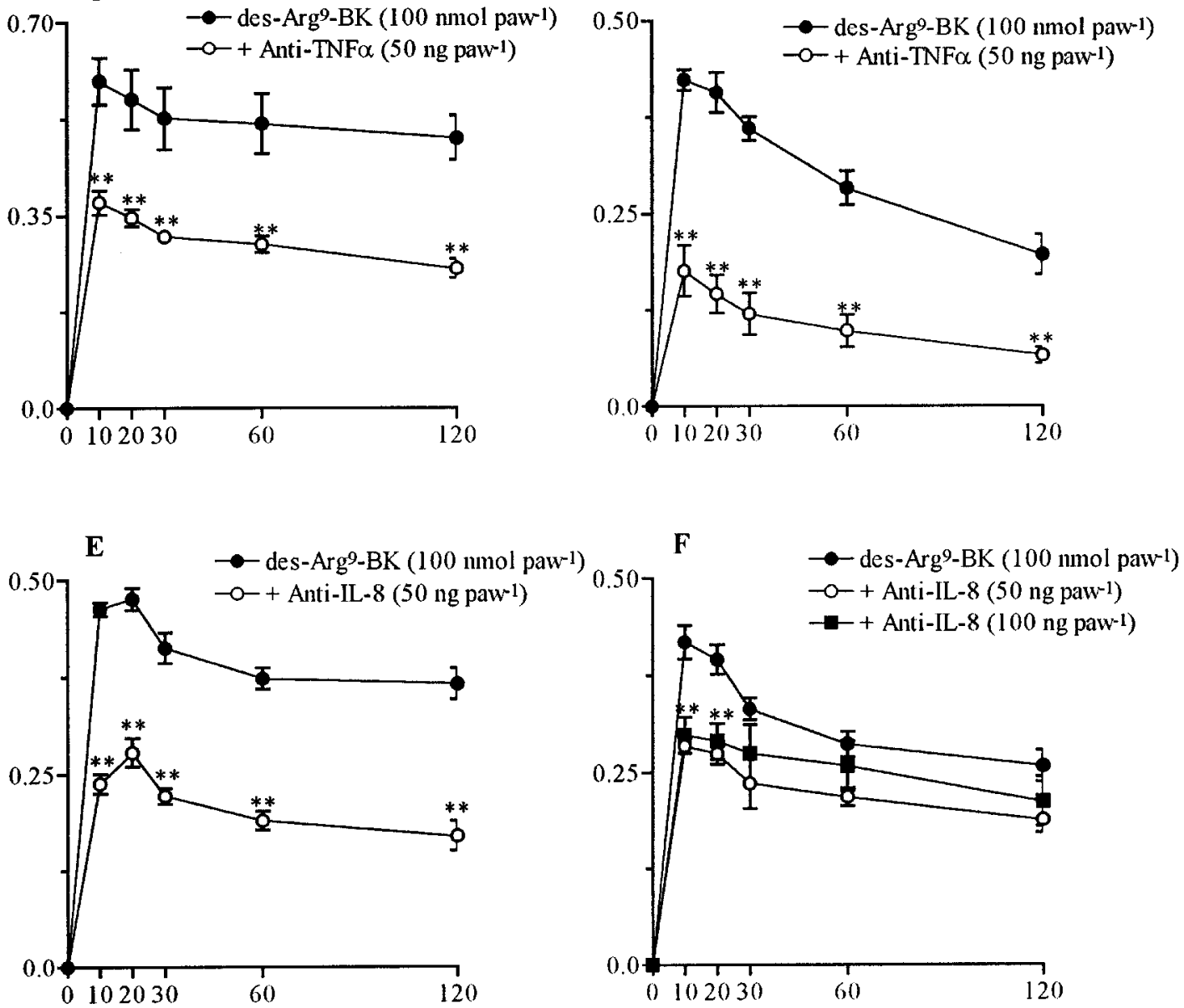

TIME AFTER INJECTION (min)

Figure 1 Effect of co-injection of anti-murine antibodies anti-IL-1 $\beta$ (A and B), anti-TNF $\alpha$ (C and D) or anti-IL-8 (E and F) on des-Arg ${ }^{9}$-BK-induced paw oedema in rats pre-treated with IL-1 $\beta$ (5 ng paw ${ }^{-1}, 60$ min beforehand; A, C and E) or with TNF $\alpha$ $\left(5 \mathrm{ng} \mathrm{paw}{ }^{-1}, 30 \mathrm{~min}\right.$ beforehand; $(\mathrm{B}, \mathrm{D}$ and $\mathrm{F})$ ). Values represent the differences between volumes (in ml) of vehicle-injected $(0.1 \mathrm{ml}$ of PBS solution) and drug-injected paws. Each point represents the mean \pm s.e.mean of $4-6$ rats. In some cases the error bars are hidden within the symbols. Significantly different from control values $* P<0.05 ; * * P<0.01$ (A-E, Student's unpaired $t$-test) (F, ANOVA followed by Dunnett's test). 
TNF $\alpha$ (Figure 1B, D and F) were significantly inhibited by the co-injection of the murine antibodies anti-IL-1 $\beta$, anti-TNF $\alpha$ and anti-IL-8 (50 ng paw ${ }^{-1}$ ), with inhibitions of $65 \pm 3 ; 37 \pm 3$ and $42 \pm 4 \%$ for IL- $1 \beta$, and $39 \pm 3 ; 64 \pm 6$ and $25 \pm 7 \%$ for $\mathrm{TNF} \alpha$, respectively. On the other hand, the co-injection of the anti-murine antibody anti-IL-6 (50-100 ng paw $\left.{ }^{-1}\right)$ had no effect on the rat paw oedema caused by des-Arg ${ }^{9}-\mathrm{BK}$ in animals treated with either IL- $1 \beta$ or $\mathrm{TNF} \alpha(n=4$, results not shown). The results of Figure 2 show that the combination of IL-1 receptor antagonist (IRA, $100 \mu \mathrm{g} \mathrm{paw}^{-1}$ ) or of the antiinflammatory cytokine, IL-10 (10 $\left.\mathrm{ng} \mathrm{paw}^{-1}\right)$ significantly reduced the oedema formation caused by des-Arg ${ }^{9}-\mathrm{BK}$ in rats that received IL- $1 \beta(67 \pm 4$ and $63 \pm 2 \%$; Figure $2 \mathrm{~A}$ and $\mathrm{C})$ or $\mathrm{TNF} \alpha(46 \pm 5$ and $35 \pm 5 \%$; Figure $2 \mathrm{~B}$ and $\mathrm{D})$.

The co-injection of the PKC inhibitors staurosporine $\left(10 \mathrm{nmol} \mathrm{paw}^{-1}\right.$, Figure $3 \mathrm{~A}$ and B) or RO 318220 (30 nmol paw $^{-1}$, Figure $3 \mathrm{C}$ and D), in association with either IL- $1 \beta$ or $\mathrm{TNF} \alpha$, produced significant inhibition of des-Arg'-BKinduced paw oedema. The inhibitions obtained for these drugs were: $44 \pm 3$ and $42 \pm 2 \%$ for IL- $1 \beta$, and $53 \pm 7$ and $30 \pm 3 \%$ for $\mathrm{TNF} \alpha$, respectively.

The rat paw oedema induced by des-Arg ${ }^{9}-\mathrm{BK}$ in rats treated with either IL- $1 \beta$ or TNF $\alpha$ was markedly inhibited by previous treatment of animals with the tyrosine kinase inhibitor, genistein $\left(2.5 \mathrm{mg} \mathrm{kg}^{-1}\right.$, s.c., 30 min prior to the cytokines) (58 \pm 3 and $31 \pm 8 \%$ of inhibition for IL- $1 \beta$ and TNF $\alpha$, respectively) (Figure 4A and $\mathrm{B}$ ). In addition, the co-injection of the MAP-kinase inhibitor PD 098059 (30 $\mathrm{nmol} \mathrm{paw}^{-1}$ ) significantly inhibited des-Arg-BK-induced paw oedema by $39 \pm 4$ and $35 \pm 7 \%$, in rats pre-treated with IL- $1 \beta$ (Figure 4C) or with TNF $\alpha$ (Figure 4D), respectively.

The results of Figure 5 demonstrate that the pre-treatment of animals with the NF- $\kappa \mathrm{B}$ inhibitors, TLCK $\left(2 \mathrm{mg} \mathrm{kg}^{-1}\right.$, i.p. $)$ or PDCT (100 $\mathrm{mg} \mathrm{kg}^{-1}$, i.p.), both $30 \mathrm{~min}$ before, significantly inhibited the increase in paw volume produced by des-Arg'$\mathrm{BK}$ in rats pre-treated with either IL- $\beta(27 \pm 4$ and $83 \pm 3 \%)$ or with $\mathrm{TNF} \alpha(28 \pm 6$ and $80 \pm 2 \%)$, respectively. Additional doses of the inhibitors staurosporine, RO 318220 or PD 098059 (up to $50 \mathrm{nmol} \mathrm{paw}^{-1}$ ) or genistein (up to $5 \mathrm{mg} \mathrm{kg}^{-1}$ ) did not display any further inhibition of $\mathrm{B}_{1}$ receptor-mediated rat paw oedema (results not shown, $n=4$ ). In the case of TLCK, it was not possible to test doses superior to $2 \mathrm{mg} \mathrm{kg}^{-1}$, because it produced some toxic effects.

Finally, the treatment of animals with RO 318220, genistein, PD098059 or TLCK (at the same range of doses used above) did not display any significant effect on rat paw oedema induced by BK ( $\left.3 \mathrm{nmol} \mathrm{paw}{ }^{-1}\right)$ (Table 1$)$. On the other hand the oedema formation mediated by BK was
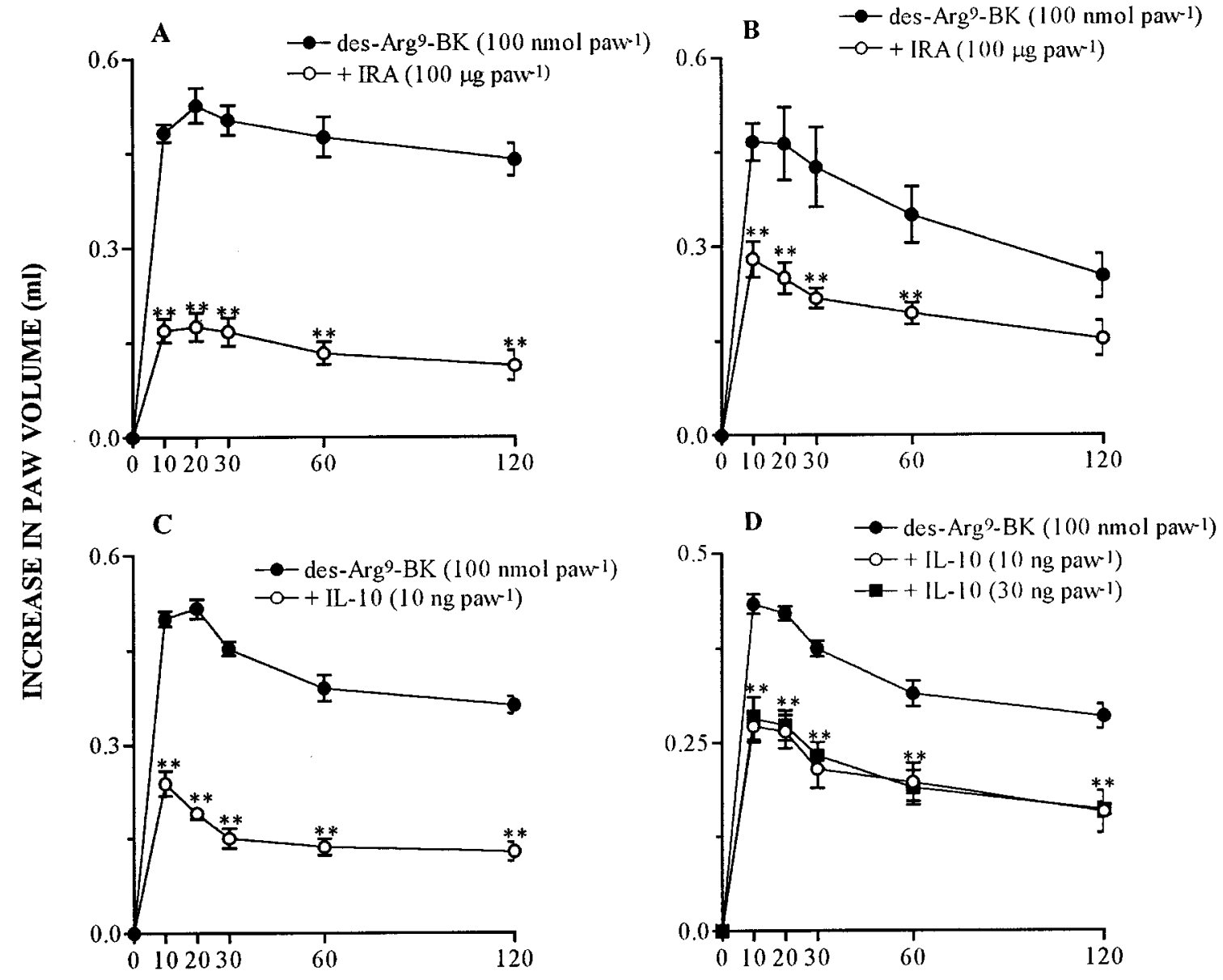

TIME AFTER INJECTION ( $\mathrm{min})$

Figure 2 Effect of co-injection of the recombinant human IL-1 antagonist (IRA, A and B) or of IL-10 (C and D) on des-Arg ${ }^{9}$-BKinduced paw oedema in rats pre-treated with IL-1 $\beta\left(5 \mathrm{ng} \mathrm{paw}^{-1}, 60 \mathrm{~min}\right.$ beforehand; (A and C)) or with TNF $\alpha\left(5 \mathrm{ng}\right.$ paw ${ }^{-1}$, 30 min beforehand; (B and D)). Values represent the differences between volumes (in $\mathrm{ml}$ ) of vehicle-injected ( $0.1 \mathrm{ml}$ of PBS solution) and drug-injected paws. Each point represents the mean \pm s.e.mean of $4-6$ rats. In some cases the error bars are hidden within the symbols. Significantly different from control values $* P<0.05 ; * * P<0.01$ (A-C, Student's unpaired $t$-test) (D, ANOVA followed by Dunnett's test). 
A

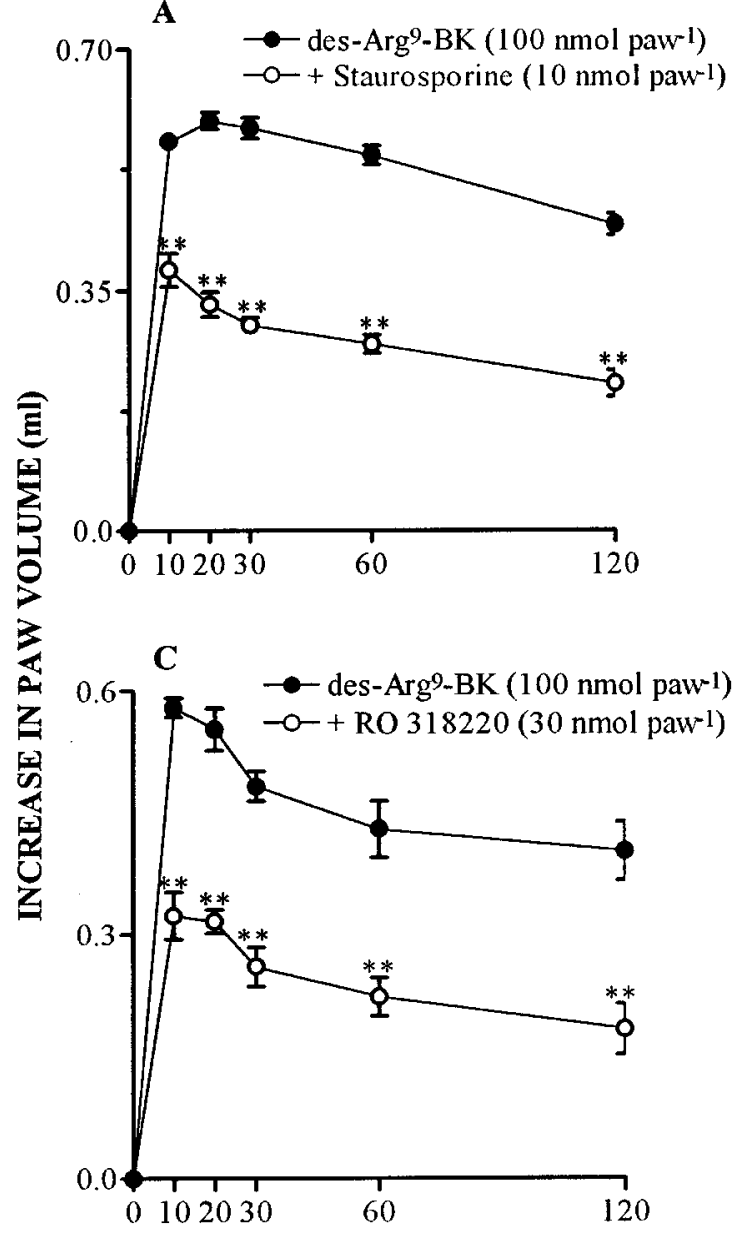

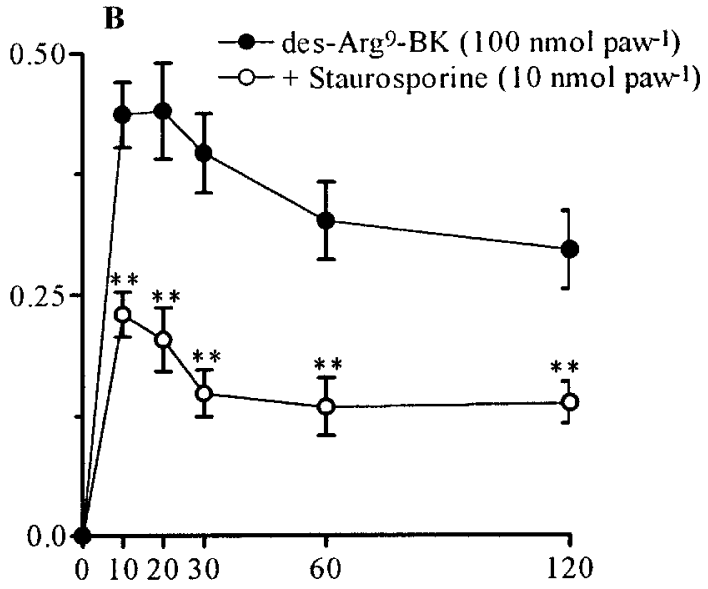

D

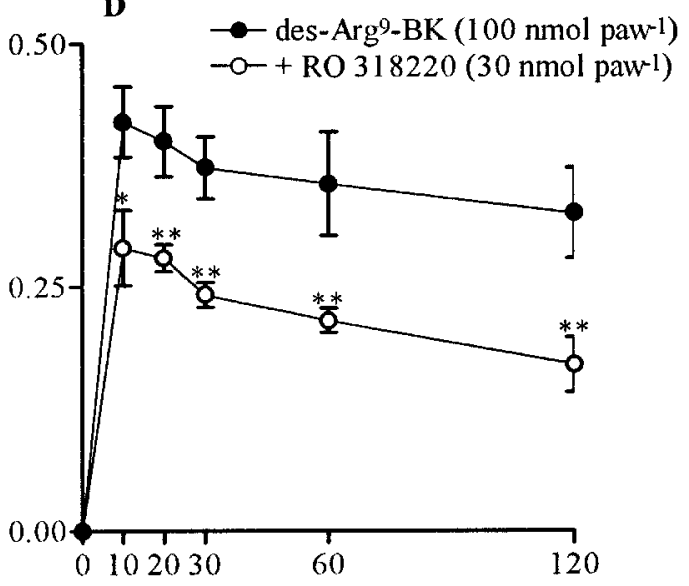

TIME AFTER INJECTION (min)

Figure 3 Effect of co-injection of staurosporine (A and B) or of RO 319220 (C and D) on des-Arg ${ }^{9}$-BK-induced paw oedema in

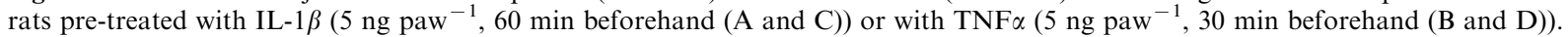
Values represent the differences between volumes (in $\mathrm{ml})$ of vehicle-injected $(0.1 \mathrm{ml}$ of PBS solution) and drug-injected paws. Each point represents the mean \pm s.e.mean of $4-6$ rats. In some cases the error bars are hidden within the symbols. Significantly different from control values $* P<0.05 ; * * P<0.01$ (Student's unpaired $t$-test).

slightly, but significantly inhibited by staurosporine $(29 \pm 8 \%)$ or PDTC $(24 \pm 4 \%)$.

\section{Discussion}

Despite the evidence showing the upregulation of $\mathrm{B}_{1}$ kinin receptors following several inflammatory stimuli or after tissue trauma, the precise mechanisms involved in this effect are still not completely understood. The increase of functional responses mediated by $\mathrm{B}_{1}$ receptors has been extensively reported for both in vitro and in vivo models. We have previously demonstrated that the complete desensitization of the rat paw oedema after repeated injection of either BK or tyrosine ${ }^{8}-\mathrm{BK}$ results in the upregulation $\mathrm{B}_{1}$ receptors-mediated responses (Campos \& Calixto, 1995). Similar induction of $\mathrm{B}_{1}$ receptors-mediated oedema formation, sensitive to dexamethasone and cyclohexymide treatments, has been shown after acute $(24 \mathrm{~h})$ treatment of animals with lypopolysaccharide of E. coli (Campos et al., 1996), following long-term systemic treatment with BCG (Campos et al., 1997) or i.d. injection of the pro-inflammatory cytokines IL- $1 \beta$ or TNF $\alpha$ (Campos et al., 1998). Therefore, such data confirm the notion that induction of $B_{1}$ receptors may be relevant in either acute or chronic inflammatory processes. In the present study, besides confirming the involvement of cytokines in this process, we also investigated the possible mechanisms responsible for the in vivo $\mathrm{B}_{1}$ receptor upregulation following i.d. treatment of animals with IL- $1 \beta$ or TNF $\alpha$.

Our results suggest that the rat paw oedema induced by des$\mathrm{Arg}^{9}$-BK after i.d. injection of IL-1 $\beta$ or TNF $\alpha$ involves the secondary production of other cytokines, since the increase in $\mathrm{B}_{1}$-receptor-mediated oedema formation was inhibited to a great extent by the co-injection of the antibodies anti-IL- $1 \beta$, anti-TNF $\alpha$ or anti-IL-8, as well as by the association of the natural IL-1 receptor antagonist, IRA. These results fully agree with other evidence indicating that the upregulation of $\mathrm{B}_{1}$ receptors depends on the local production (autocrine or paracrine) of distinct cytokines (Marceau, 1995). It has been demonstrated that the induction of $B_{1}$ receptors evoked by intra-articular injection of IL-1, IL-6 or by IL-8, in a rat model of inflammatory hyperalgesia, is consistently inhibited by coinjection of IRA, indicating that the effects of these cytokines are mediated by the release of IL-1 (Davis \& Perkins, 1994; for 
A

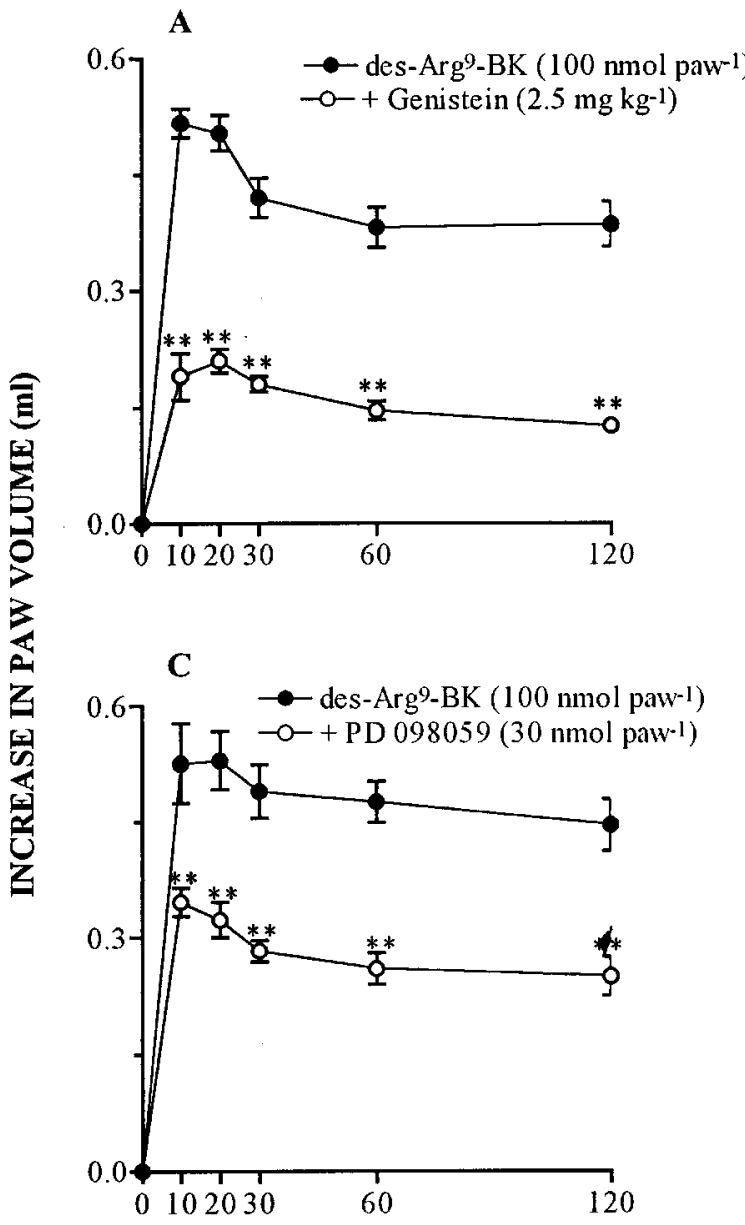

B

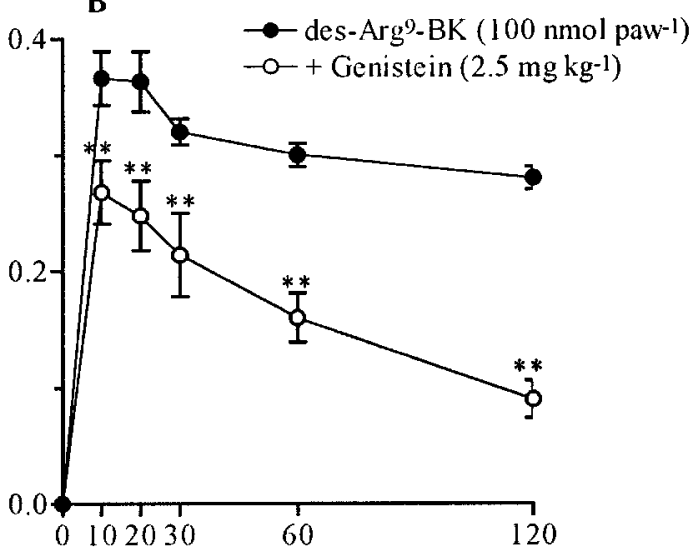

D

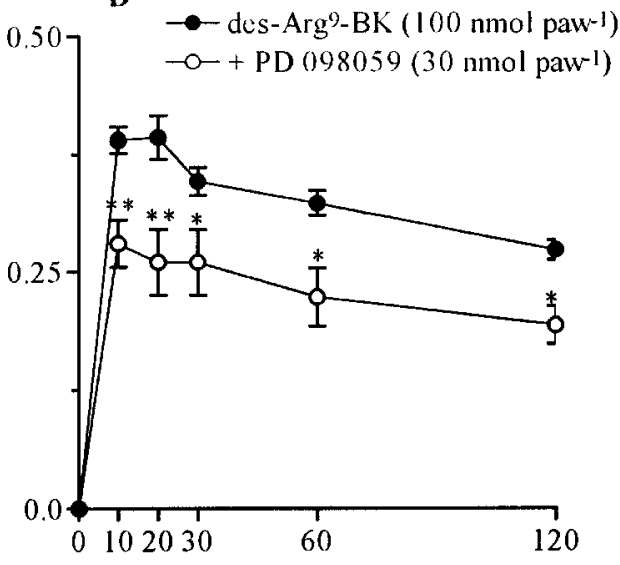

TIME AFTER INJECTION (min)

Figure 4 Effect of systemic treatment with genistein (A and B) or with PD 098059 (C and D) on des-Arg ${ }^{9}$-BK-induced paw oedema

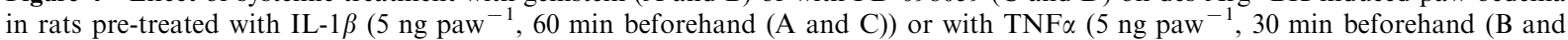
D)). Values represent the differences between volumes (in $\mathrm{ml})$ of vehicle-injected $(0.1 \mathrm{ml}$ of PBS solution) and drug-injected paws. Each point represents the mean \pm s.e.mean of 4-6 rats. In some cases the error bars are hidden within the symbols. Significantly different from control values $* P<0.05$; ** $P<0.01$ (Student's unpaired $t$-test).

review see Marceau, 1997). Furthermore, our data also demonstrate that the upregulation of kinin $\mathrm{B}_{1}$ receptormediated oedema formation was significantly inhibited by co-injection of IL-10, an important anti-inflammatory cytokine which induces downregulation of pro-inflammatory cytokines, mainly IL-1 $\beta$ and TNF $\alpha$ at the site of inflammation (Firestein \& Zvaifler, 1997; Nikolaus et al., 1998). In contrast to results reported in the rabbit aorta in vitro (DeBlois et al., 1988) using human recombinat $\mathrm{TNF} \alpha$, this study, together with the results of a previous one (Campos et al., 1998), clearly demonstrate that i.d. treatment with murine $\mathrm{TNF} \alpha$ largely mediates the upregulation of the $\mathrm{B}_{1}$ receptor agonist des-Arg'BK-mediated oedema formation in the rat paw. In addition, our results are in line with those recently reported by Ni et al. (1998), affirming that human $\mathrm{TNF} \alpha$ up-regulates $\mathrm{B}_{1}$ receptor gene expression and increases $\mathrm{NF}-\kappa \mathrm{B}$ binding activity in vascular smooth muscle.

It has been suggested that activation of some classes of protein kinases are meaningful to the induction of $B_{1}$ kinin receptor. Recently, it has been demonstrated that both spontaneous and IL- $1 \beta$-induced upregulation of $\mathrm{B}_{1}$ receptor in rabbit aorta is very sensitive to some MAP-kinase inhibitors, e.g. PD98059, an agent which inhibits MAP kinases activated by extracellular signals or by the p38 MAP kinase inhibitor, SB203580 (Larrivé et al., 1998). Our data confirm and extend these findings, and demonstrate for the first time the involvement of MAP kinase pathways in $\mathrm{B}_{1}$ receptor upregulation in vivo, following i.d. injection of the proinflammatory cytokines, IL- $1 \beta$ or $\mathrm{TNF} \alpha$. This conclusion arises from the fact that oedema caused by des- $\mathrm{Arg}^{9}-\mathrm{BK}$ was significantly prevented by the co-injection of the MAP kinase inhibitor, PD 98059. The activation of MAP-kinases cascades occur in response to several stimuli including inflammatory cytokines (IL-1 $\beta$ and TNF $\alpha$ ), heat and chemical shock, or bacterial products, all capable of stimulating the $\mathrm{B}_{1}$ receptor induction (Paul et al., 1997). In addition, MAP-kinases seem to be important pathways responsible for the link between some transcriptional factors (e.g. NF- $\kappa \mathrm{B}$ ) and intracellular signals (Larrivé et al., 1998; Yamakawa et al., 1998).

Also relevant are the results demonstrating that the previous treatment of animals with the tyrosine kinase inhibitor genistein produced a marked inhibition of $B_{1}$ receptor-mediated rat paw oedema in animals that had received IL-1 $\beta$ or TNF $\alpha$. The involvement of tyrosine kinase pathways in $B_{1}$ kinin receptor upregulation has recently been reported for rabbit aortic strips, since the treatment of 
A

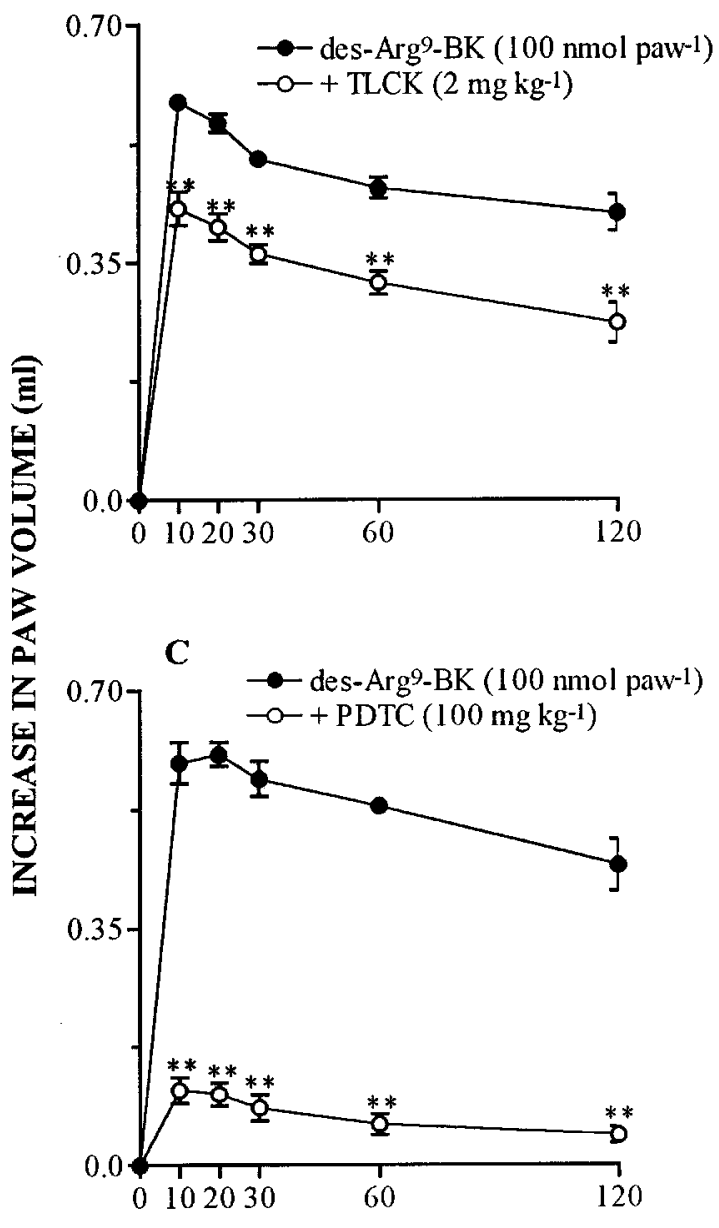

B
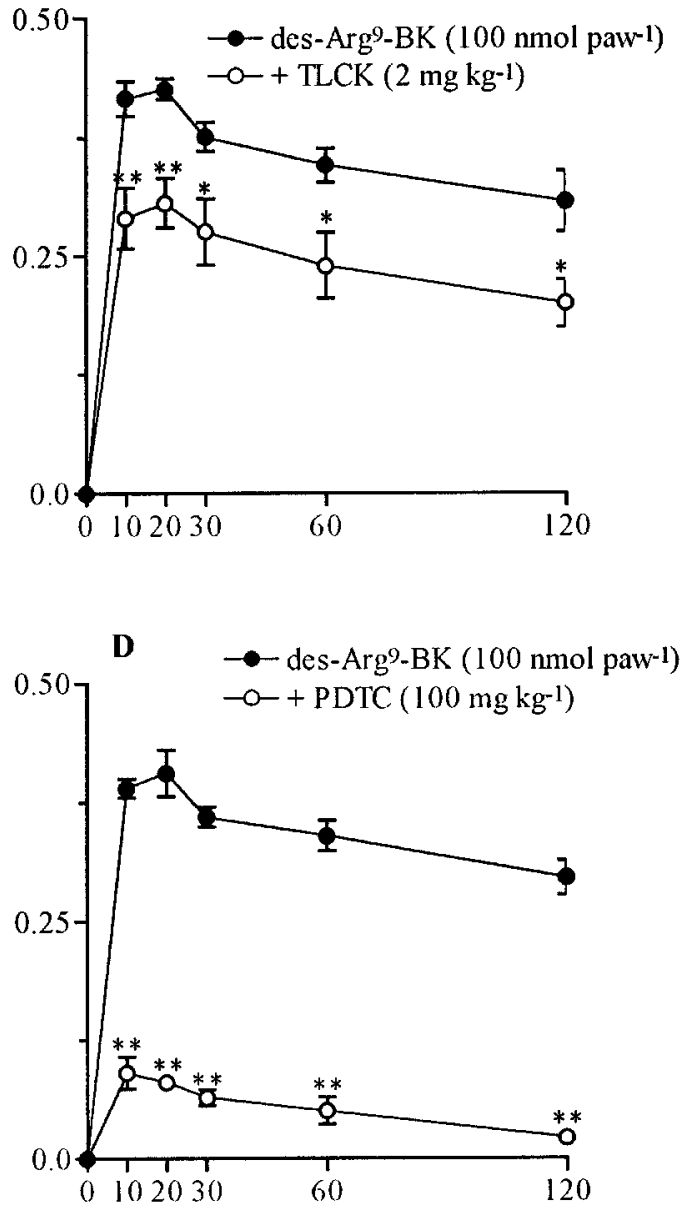

TIME AFTER INJECTION ( $\mathrm{min})$

Figure 5 Effect of systemic treatment with TLCK (A and B) or with PDCT (C and D) on des-Arg ${ }^{9}$-BK-induced paw oedema in rats pre-treated with IL- $1 \beta\left(5 \mathrm{ng} \mathrm{paw}^{-1}, 60 \mathrm{~min}\right.$ beforehand (A and C)) or with TNF $\alpha\left(5 \mathrm{ng}^{-1}, 30 \mathrm{~min}^{-1}\right.$ beforehand (B and D)). Values represent the differences between volumes (in $\mathrm{ml})$ of vehicle-injected $(0.1 \mathrm{ml}$ of PBS solution) and drug-injected paws. Each point represents the mean \pm s.e.mean of $4-6$ rats. In some cases the error bars are hidden within the symbols. Significantly different from control values $* P<0.05 ; * * P<0.01$ (Student's unpaired $t$-test).

Table 1 Effect of several classes of drugs on BK-induced rat paw oedema

\begin{tabular}{|c|c|}
\hline & $\begin{array}{c}\text { Oedema } \\
\text { formation }(\mathrm{ml})^{a}\end{array}$ \\
\hline $\begin{array}{l}\text { Control }\left(\mathrm{BK} 3 \mathrm{nmol} \mathrm{paw}{ }^{-1}\right) \\
\text { + Staurosporine }\left(10 \mathrm{nmol} \mathrm{paw}^{-1}\right) \\
\text { + RO } 318220\left(30 \mathrm{nmol} \mathrm{paw}^{-1}\right) \\
\text { + PD } 098059\left(10 \mathrm{nmol}^{-1}\right) \\
\text { + Genistein }\left(2.5 \mathrm{mg} \mathrm{kg}^{-1}, \text { s.c., } 30 \mathrm{~min}\right) \\
\text { + TLCK }\left(2 \mathrm{mg} \mathrm{kg}^{-1} \text {, i.p., } 30 \mathrm{~min}\right) \\
\text { + PDTC }\left(100 \mathrm{mg} \mathrm{kg}^{-1} \text {, i.p., } 30 \mathrm{~min}\right)\end{array}$ & $\begin{array}{l}0.40 \pm 0.02 \\
0.28 \pm 0.04^{* *} \\
0.38 \pm 0.04 \\
0.40 \pm 0.03 \\
0.44 \pm 0.03 \\
0.37 \pm 0.02 \\
0.30 \pm 0.02 * *\end{array}$ \\
\hline \multicolumn{2}{|c|}{$\begin{array}{l}\text { Each group represents the mean } \pm \text { s.e.mean of } 4-5 \text { experi- } \\
\text { ments. ancrease in paw volume }(\mathrm{ml}) \text { measured } 20 \text { min after } \\
\text { injection of peptides. Significantly different from control } \\
\text { values. } * * P<0.01 \text { (ANOVA followed by Dunnett's test). }\end{array}$} \\
\hline
\end{tabular}

preparations with genistein significantly prevented the contraction produced by des-Arg'-BK (Larrivé et al., 1998).

It has been described that PKC is directly related to functional and morphological changes in endothelial cells, being responsible for some effects observed in response to important inflammatory mediators such as BK or TNF $\alpha$ (Ross et al., 1997). Thus, PKC appears to be activated and involved in the sequential activation of MAP kinases following treatment with BK (Lal et al., 1998). Our results clearly demonstrate an involvement of $\mathrm{PKC}$ in the upregulation of $\mathrm{B}_{1}$ receptor after i.d. injection of IL- $1 \beta$ or $\mathrm{TNF} \alpha$, since the rat paw oedema produced by des-Arg ${ }^{9}$-BK was notably inhibited by the two PKC inhibitors staurosporine and RO 318220. Also, the present results are in agreement with recent evidence showing that the pre-treatment of human lung fibroblasts with the PKC inhibitor, GF 109203, prevents in a significant manner the expression of $B_{1}$ kinin receptor RNAm, induced by the $\mathrm{B}_{1}$ agonist des- $\mathrm{Arg}^{10}$-kallidin (Schanstra et al., 1998).

Another interesting aspect investigated in the present work was the participation of the transcriptional factor NF- $\kappa \mathrm{B}$ in the $\mathrm{B}_{1}$ receptor up-regulation in vivo. There are some in vitro studies showing that induction of $\mathrm{B}_{1}$ receptors is directly related to previous activation of $\mathrm{NF}-\kappa \mathrm{B}$. Thus, it has been demonstrated that in cultured human lung fibroblasts, the $\mathrm{B}_{1}$ receptor upregulation induced by IL- $\beta$ is modulated at the transcriptional level, in a process mediated by the activation of 
$\mathrm{NF}-\kappa \mathrm{B}$ (Schanstra et al., 1998). In addition, the presence of an $\mathrm{NF}-\kappa \mathrm{B}$ like sequence on $\mathrm{B}_{1}$ receptor promoter, has recently been shown, which seems to be mainly responsible for the inducibility of the receptor in response to IL- $1 \beta, \mathrm{TNF} \alpha$ or LPS (Ni et al., 1998). In the present study, we have demonstrated for the first time the involvement of $\mathrm{NF}-\kappa \mathrm{B}$ pathway in $\mathrm{B}_{1}$ kinin receptor upregulation in vivo. This inference is a consequence of the fact that the paw oedema caused by des$\mathrm{Arg}^{9}-\mathrm{BK}$, in rats which have received the pro-inflammatory cytokines IL- $1 \beta$ or $\mathrm{TNF} \alpha$, was significantly prevented by the systemic pre-treatment of animals with NF- $\kappa \mathrm{B}$ inhibitors, PDCT or TLCK. The inhibition of most of the tested drugs on des-Arg ${ }^{9}$-BK, seems to be mediated by a selective mechanism, as the paw oedemas induced by BK, which involve an action on $\mathrm{B}_{2}$ constitutive receptors, were not affected. However, part of the inhibitory action of staurosporine and PDTC on desArg ${ }^{9}$-BK-mediated paw oedema may involve additional mechanisms, not related to $B_{1}$ receptor inhibition.

These results confirm and also extend the recently-reported in vitro evidence (Ni et al., 1998; Schanstra et al., 1998) and are consistent with the notion that the inflammatory cytokines such as IL- $1 \beta$ and $\mathrm{TNF} \alpha$ can activate $\mathrm{NF}-\kappa \mathrm{B}$ which in turn increases their expression and jointly stimulates the upregulation of $\mathrm{B}_{1}$ receptors. It has recently been demonstrated that the anti-inflammatory cytokines IL-10 and IL-13 are capable of suppressing activation of $\mathrm{NF}-\kappa \mathrm{B}$ in alveolar macrophages
(Lentsch et al., 1997). As IL-10 was found to be effective in preventing the oedema formation caused by des-Arg'-BK in animals treated with $\mathrm{IL}-1 \beta$ and $\mathrm{TNF} \alpha$ it is tempting to speculate that the modulation of anti-inflammatory cytokines levels and the activation of $\mathrm{NF}-\kappa \mathrm{B}$ might be one of the main cellular mechanisms responsible for the upregulation of $\mathrm{B}_{1}$ receptors following i.d. treatment with inflammatory cytokines.

In conclusion, the current results give for the first time, strong evidence indicating that the in vivo up-regulation of $\mathrm{B}_{1}$ receptor mediated rat paw oedema, following i.d. treatment of animals with IL- $1 \beta$ or TNF $\alpha$, involves the additional release of other cytokines such as IL- $1 \beta$, TNF $\alpha$ and IL-8. Furthermore, our results also clearly demonstrate that activation of protein kinases such as PKC, tyrosine kinase or MAP-kinases, and the transcription factor $\mathrm{NF}-\kappa \mathrm{B}$, has a critical in vivo role in modulating the upregulation of des-Arg ${ }^{9}-\mathrm{BK}$ induced paw oedema in rats treated with the pro-inflammatory cytokines IL- $1 \beta$ or TNF $\alpha$. Together, the present results provide additional evidence supporting the role played by $\mathrm{B}_{1}$ receptors in controlling and maintaining of inflammatory processes.

This work was supported by grants from CNPq, FINEP and FAPESP (Brazil). M.M. Campos is a PhD student receiving a grant from $\mathrm{CNPq}$.

\section{References}

BARNES, P.J. \& ADCOCK, I.M. (1997). NF- $\kappa$ B: a pivotal role in asthma and a new target for therapy. Trends Pharmacol. Sci., 18, $47-50$.

BARNES, P.J. \& KARIN, M. (1997). Nuclear factor- $\kappa$ B-a pivotal transcription factor in chronic inflammatory diseases. N. Eng. $J$. Med., 336, $1066-1071$.

BHOOLA, K.D., FIGUEROA, C.D. \& WORTHY, K. (1992). Biorregulation of kinins: kallikreins, kininogens, and kininases. Pharmacol. Rev., 44, 1-80.

CAMPOS, M.M. \& CALIXTO, J.B. (1995). Involvement of $\mathrm{B}_{1}$ and $\mathrm{B}_{2}$ receptors in bradykinin-induced rat paw oedema. $\mathrm{Br} . \mathrm{J}$. Pharmacol., 114, 1005-1013.

CAMPOS, M.M., HENRIQUES, M.G.M.O. \& CALIXTO, J.B. (1997). The role of $\mathrm{B}_{1}$ and $\mathrm{B}_{2}$ receptors in oedema formation after long-term treatment with Mycobacterium bovis bacillus Calmette-Guérin (BCG). Br. J. Pharmacol., 120, 502-508.

CAMPOS, M.M., SOUZA, G.E.P. \& CALIXTO, J.B. (1996). Upregulation of $\mathrm{B}_{1}$ mediating des-Arg ${ }^{9}$-BK-induced rat paw oedema by systemic treatment with bacterial endotoxin. Br. J. Pharmacol., 117, $793-798$.

CAMPOS, M.M., SOUZA, G.E.P. \& CALIXTO, J.B. (1998). Modulation of kinin $\mathrm{B}_{1}$ receptor-mediated rat paw ooedema by IL- $1 \beta$ and TNF $\alpha$. Peptides, 19, $1269-1276$.

CORRÊA, C.R. \& CALIXTO, J.B. (1993). Evidence for participation of $\mathrm{B}_{1}$ and $\mathrm{B}_{2}$ kinin receptors in formalin-induced nociceptive response in the mouse. Br. J. Pharmacol., 110, 193-198.

DAVIS, A.J. \& PERKINS, M.N. (1994). Induction of $B_{1}$ receptors in vivo in a model of persistent inflammatory mechanical hyperalgesia in the rat. Neuropharmacol., 33, 127-133.

DEBLOIS, D., BOUTHILlIER, J. \& MARCEAU, F. (1988). Effect of glucocorticoids, monokines and growth factor on the spontaneously developing responses of the rabbit isolated aorta to desArg ${ }^{9}$-Bradykinin. Br. J. Pharmacol., 93, 969-977.

DONALDSON, L.F., HANLEY, M.R. \& VILLABRANCA, A.C. (1997). Inducible receptors. Trends Pharmacol. Sci., 18, 171-181.

EGGERIX, D., RASPE, E., BERTRAND, D., VASSART, G. \& PARMENTIER, M. (1992). Molecular cloning, functional expression and pharmacological characterization of human bradykinin $\mathrm{B}_{2}$ receptor gene. Biochem. Biophys. Res. Commun., 187, 13061313.

FIRESTEIN, G.S. \& ZVAIFLER, N.J. (1997). Anticytokine therapy in rheumatoid arthritis. N. Eng. J. Pharmacol., 337, 195-197.
GHODA, L., LIN, X. \& GREENE, W.C. (1997). The 90-kDa ribosomal S6 kinase (pp90rsk) phophorylates the N-terminal regulatory domain of $1-\kappa \mathrm{B}$ alpha and stimulates its degradation in vitro. $J$. Biol. Biochem., 272, $21281-21288$.

HALL, J.M. (1992). Bradykinin receptors: pharmacological properties and biological roles. Pharmacol. Ther., 56, $131-190$.

HALL, J.M. (1997). Bradykinin receptors. Gen. Pharmacol., 28, 1 -6.

HALL, J.M. \& MORTON, I.K.M. (1997). The pharmacology and immunopharmacology of kinin receptors. In: Farmer, S.G. (ed.) The Kinin System, Academic Press, New York, pp. 9-43.

HESS, J.F., BORKOWSKI, J.A., MACNEIL, T., STONESIFER, T.G.Y., FRAHER, J., STRADER, C.D. \& RANSOM, R.W. (1994). Differential pharmacology of cloned human and mouse $\mathrm{B}_{2}$ bradykinin receptors. Mol. Pharmacol., 45, 1-8.

HESS, J.F., BORKOWSKI, J.A., YOUNG, G.S., STRADER, C.D. \& RANSOM, R.W. (1992). Cloning and pharmacological characterization of a human bradykinin $\mathrm{B}_{2}$ receptor. Biochem. Biophys. Res. Commun., 184, 260-268.

LAL, M.A., PROULX, P.R. \& HEBERT, R.L. (1998). A role for PKC epsilon and MAP kinase in bradykinin-induced arachidonic acid release in rabbit CCD cells. Am. J. Physiol., 43, 728-735.

LARRIVÉE, J-F., BACHVAROV, D.R., HOULE, F., LANDRY, J., HUOT, J. \& MARCEAU, F. (1998). Role of the mitogen-activated protein kinases in the expression of the kinin $B_{1}$ receptors induced by tissue injury. J. Immunol., 160, 1419-1426.

LENTSCH, A.B., SHANLEY, T.P., SARMA, V. \& WARD, P.A. (1997). In vivo suppression of $\mathrm{NF}-\kappa \mathrm{B}$ and preservation of $1 \kappa \mathrm{B} \alpha$ by interleukin-10 and by interleukin-13. J. Clin. Invest., 100, $2443-2448$.

MARCEAU, F. (1995). Kinin $\mathrm{B}_{1}$ receptors: a review. Immunopharmacology, 30, $1-26$.

MARCEAU, F. (1997). Kinin $B_{1}$ receptor induction and inflammation. In: Farmer, S.G. (ed.). The Kinin System, Academic Press, New York, pp. 143-153.

MCEACHERN, A.E., SHELTON, E.R., BHAJTA, S., OBERNOLT, R., BACH, C., ZUPPAN, P., FUJISAKI, J., ALDRISH, R.W. \& JARNAGIN, K. (1991). Expression cloning of rat $B_{2}$ bradykinin receptor. Proc. Natl. Acad. Sci. U.S.A, 88, 7724-7728.

NI, A., CHAO, L. \& CHAO, J. (1998). Transcription factor nuclear factor $\kappa \mathrm{B}$ regulates the inducible expression of the human $\mathrm{B}_{1}$ receptor gene in inflammation. J. Biol. Chem., 273, 2784-2791. 
NIKOLAUS, S., BAUDITZ, J., GIONCHETTI, P., WITT, C., LOCHS, H. \& SCHREIBER, S. (1998). Increased secretion of pro-inflammatory cytokines by circulating polymorphonuclear neutrophils and regulation by interleukin 10 during intestinal inflammation. Gut, 42, $470-476$

PAUL, A., WILSON, S., BELHAM, C.M., ROBINSON, C.J., SCOTT, P.H., GOULD, G.W. \& PLEVIN, R. (1997). Stress-activated protein kinases: activation, regulation and function. Cell Signal., 9, 403410

PESQUERO, J.B., PESQUERO, J.L., OLIVEIRA, S.M., ROSCHER, A.A., METZGER, R., GANTEN, D. \& BADER, M. (1996). Molecular cloning and functional characterisation of a mouse bradykinin $\mathrm{B}_{1}$ receptor gene. Biochem. Biophys., 220, 219-225.

REGOLI, D. \& BARABÉ, J. (1980). Pharmacology of bradykinin and related kinins. Pharmacol. Rev., 32, $1-46$.

ROSS, D. \& JOYNER, W.L. (1997). Resting distribution and stimulated translocation of protein kinase $\mathrm{C}$ isoforms alpha, epsilon and zeta in response to bradykinin and TNF in human endothelial cells. Endothelium., 5, 321-332.
SCHANSTRA, J.P., BATAILlÉ, E., CASTAÑO, M.E.M., BARASCUD, Y., HIRTZ, C., PESQUERO, J.B., PECHER, C., GAUTHIER, F.,

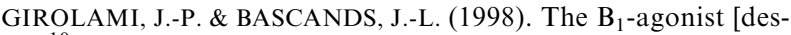
$\mathrm{Arg}^{10}$ ]-kallidin activates transcription factor NF- $\kappa \mathrm{B}$ and induces homologous upregulation of the bradykinin $\mathrm{B}_{1}$-receptor in cultured human lung fibroblasts. J. Clin. Invest., 101, 2080-2091. WHITMARSH, A.J. \& DAVIS, R.J. (1996). Transcription factor AP-1 regulation by mitogen-activated protein kinase signal transduction pathways. J. Mol. Med., 74, 589-607.

YAMAKAWA, T., EGUCHI, S., YAMAKAWA, Y., MOTLEY, E.D., NUMAGUCHI, K., UTSUNOMIYA, H. \& INAGAMI, T. (1998). Lysophosphatidylcholine stimulates MAP kinase activity in rat vascular smooth muscle cells. Hypertension, 31, 248-253.

ZIMMERMANN, M. (1983). Ethical guidelines for investigations of experimental pain in conscious animals. Pain, 16, 109-110.

(Received 14 December, 1998 Revised 5 May, 1999 Accepted 11 May, 1999) 